\title{
PENGARUH MINAT DAN PENGGUNAAN METODE TERHADAP HASIL BELAJAR IPA BIOLOGI SISWA KELAS VII SMP NEGERI 2 JAYAPURA
}

\author{
Mikael Nesi ${ }^{1}$, Maik Akobiarek ${ }^{2}$ \\ SMP Negeri Soimiangga Waropen ${ }^{1}$, Universitas Cenderawasih Jayapura ${ }^{2}$ \\ akobiarekmaik@gmail.com ${ }^{1}$
}

\begin{abstract}
ABSTRAK
Penelitian ini bertujuan untuk mengetahui pengaruh minat dan metode pembelajaran Lembar Kerja Siswa (LKS) model Word Square terhadap hasil belajar IPA Biologi siswa kelas VII SMP Negeri 2 Jayapura. Populasi penelitian adalah seluruh siswa kelas VII SMP Negeri 2 Jayapura. Sampel penelitian ini adalah siswa kelas VIIJ, VIIK, dan VIIL yang dibagi menjadi 4 kelas. Analisis data menggunakan pengujian prasyarat dengan jalur analisis yang bersifat parametrik dengan pengujian normalitas, pengujian homogenitas, dan data variabel angket minat. Sedangkan pengujian hipotesis menggunakan anava dua jalan. Hasil penelitian menunjukkan (1) Terdapat pengaruh minat yang timbul dari dalam diri siswa terhadap hasil belajar yang dicapai dalam proses pembelajaran dengan hasil perhitungan variabel minat tinggi rata-rata 74,87 dan variabel minat rendah rata-rata 65.04. (2) Terdapat pengaruh rata-rata hasil belajar IPA Biologi pada siswa yang diajar menggunakan Lembar Kerja Siswa (LKS) Model Word Square dari pada siswa yang diajar menggunakan metode ceramah pada siswa yang memiliki minat tinggi hasilnya $F_{\text {hitung }}=2.967>F_{\text {tabel }}=2.46$. (3) Terdapat perbedaan pengaruh rata-rata hasil belajar IPA Biologi pada siswa yang diajar menggunakan Lembar Kerja Siswa (LKS) Model Word Square dari pada siswa yang diajar menggunakan metode ceramah pada siswa yang memiliki minat rendah hasilnya $F_{\text {hitung }}=2.952>F_{\text {tabel }}=2.46$. (4) Terdapat pengaruh yang sangat signifikan antara metode pembelajaran dan minat atau pengaruh metode terhadap hasil belajar IPA Biologi bergantung pada minat siswa hasilnya $F_{\text {hitung }}=3.776>$ $\mathrm{F}_{\text {tabel }}=2.46$.
\end{abstract}

Katakunci : model word square, minat, hasil belajar

\begin{abstract}
This study aims to determine the effect of interest and learning methods of Word Square Student Worksheet (LKS) on the learning outcomes of Biology Science VII grade students of SMP Negeri 2 Jayapura. The study population was all grade VII students of SMP Negeri 2 Jayapura. The sample of this study were students of class VIIJ, VIIK, and VIIL which were divided into 4 classes. Data analysis used prerequisite tests with parametric analysis paths with normality testing, homogeneity testing, and interest questionnaire variable data. Whereas hypothesis testing uses two-way anava. The results showed (1) There is an influence of interest arising from within students on learning outcomes achieved in the learning process with the results of the calculation of the variable high interest on average 74.87 and the variable low interest on average 65.04. (2)
\end{abstract}


There is an influence on the average learning outcomes of Biology Science in students taught using the Word Square Model Student Worksheet (LKS) than students taught using the lecture method to students who have high interest results Fcount $=2,967>$ Ftable $=2.46$. (3) There is a difference in the average effect of learning outcomes in Biology Natural Sciences in students taught using the Word Square Model Student Worksheet (LKS) than students taught using the lecture method to students who have low interest results Fcount $=2.952>$ Ftable $=2.46$.

(4) There is a very significant influence between the learning method and the interest or the effect of the method on the learning outcomes of Natural Sciences in Biology depending on the students' interest. The result is Fcount $=3.776$ > Ftable $=2.46$.

Keywords: word square model, interests, learning outcomes

\section{PENDAHULUAN}

Pendidikan merupakan suatu kegiatan interaksi guru dan siswa serta berbagai sumber belajar. Belajar merupakan unsur penting dalam penyelenggaraan jenis dan jenjang pendidikan formal di sekolah. Menurut Slameto (2003), belajar adalah proses dihasilkannya perubahan tingkah laku karena adanya interaksi dengan lingkungan guna memenuhi kebutuhan hidup atau merupakan usaha seseorang untuk mengalami perubahan tingkah laku baru secara keseluruhan berdasarkan pengalamannya sendiri dalam berinteraksi dengan lingkungannya. Perubahan tersebut dapat tercapai apabila siswa mengalami proses belajar dan menunjukan suatu bentuk peningkatan seperti pengetahuan, kecakapan, daya pikir dan sikap sebagai akibat proses adanya interaksi. sukses atau tidaknya pencapaian terhadap tujuan pendidikan sangat tergantung dari proses belajar yang siswa alami baik ketika mereka di sekolah, lingkungan rumah atau keluarganya sendiri.

Untuk mencapai prestasi yang baik, tidak hanya dibutuhkan kecerdasan, tetapi juga minat belajar yang tumbuh dari diri siswa. Tanpa adanya minat, siswa tidak akan bergairah untuk melakukan kegiatan belajar. Slameto (2010), juga melihat minat sebagai rasa suka dan suatu keterkaitan pada sesuatu hal atau aktivitas, tanpa ada yang menyuruh. Sedangkan menurut Sudaryono, et al. (2012), apabila siswa memiliki minat pada suatu mata pelajaran, maka siswa tersebut akan terdorong untuk terlibat aktif pada kegiatan pembelajaran pada mata pelajaran tersebut. Pilihan yang menyenangkan dalam melakukan kegiatan dapat menyebabkan bangkitnya gairah seseorang untuk memenuhi kesediaannya belajar yang dapat diukur melalui kesukacitaan, ketertarikan, perhatian dan keterlibatan. Dalam hal ini, besar kecilnya minat sangat bergantung pada penerimaan akan suatu hubungan antara diri sendiri dengan sesuatu diluar dirinya. Minat dapat diekspersikan melalui suatu pernyataan yang menunjukkan bahwa siswa lebih menyukai suatu hal dari pada hal lainnya. Selain itu, minat dapat pula diwujudkan melalui peran serta siswa dalam suatu aktivitas. Siswa yang berminat terhadap 
objek tertentu cenderung untuk memberikan perhatian yang lebih besar terhadap objek tersebut.

Fakta yang terlihat di lapangan khususnya dalam proses belajar pada mata pelajaran IPA Biologi di SMP Negeri 2 Jayapura menunjukkan bahwa minat siswa dalam mengikuti proses pembelajaran terlihat kurang aktif. Karena pada umumnya guru hanya menerapkan metode ceramah, dimana penggunaan metode ceramah guru yang berperan aktif dalam menyampaikan materi. Penyampaian materi oleh guru dalam bentuk kata atau kalimat dalam proses belajar mengajar, sehingga peran siswa hanya sebagai pendengar yang pasif dalam mendengarkan penjelasan meteri dari guru. Sehingga rasa bosan yang ditunjukkan oleh siswa akan terlihat ketika siswa tidak memperhatikan penjelasan materi oleh guru tetapi bercerita dengan teman-temannya. Karena semua proses pembelajaran hanya berpusat pada guru sehingga siswa hanya diberi kesempatan untuk bertanya pada akhir pembelajaran. Akan tetapi pembelajaran ini menyebabkan minimnya perhatian siswa selama proses pembelajaran. Akibatnya, materi yang disampaikan oleh guru kadangkala mudah terlupakan oleh siswa sehingga akan berpengaruh terhadap hasil belajar yang dicapai oleh siswa setelah mengalami proses belajar oleh siswa tersebut.

Upaya untuk meningkatkan minat dan hasil belajar siswa pada proses pembelajaran IPA Biologi memerlukan sebuah metode pembelajaran yang tepat. Peran seorang guru sangat penting dalam meningkatkan minat siswa dan hasil belajar siswa. Di sisi lain, guru perlu mengubah model pembelajaran dari yang bersifat konvensional sesuai kurikulum yang menempatkan guru sebagai fasilitator. Menerapkan strategi pembelajaran yang efektif seperti penerapan metode pembelajaran yang disesuaikan dengan kebutuhan siswa dapat membantu membangkitkan minat siswa sekaligus meningkatkan hasil belajar siswa. Salah satu upaya yang digunakan peneliti meningkatkan hasil belajar siswa dengan menggunakan Lembar Kerja Siswa (LKS) Model Word Square.

Menurut Dewi (2012), pembelajaran dengan Lembar Kerja Siswa (LKS) Model Word Square merupakan model pembelajaran dimana siswa diberi kesempatan untuk selalu aktif selama proses pembelajaran dengan menekankan pembelajaran kelompok dan uji pemahaman berupa permainan (game) dengan pembelajaran Lembar Kerja Siswa (LKS) Model Word Square. Pembelajaran Lembar Kerja Siswa (LKS) Model Word Square merupakan model pembelajaran yang memadukan kemampuan menjawab pertanyaan dengan kejelian dalam mencocokkan jawaban pada kotak-kotak jawaban. Model ini mirip seperti mengisi Teka-Teki Silang tetapi bedanya jawabannya sudah ada namun disamarkan dengan menambahkan kotak tambahan dengan sembarang huruf penyamar atau pengecoh.

Berdasarkan masalah yang telah dipaparkan di atas dan belum pernah ada penelitian sebelumnya dengan menggunakan LKS model Word Square membuat peneliti tertarik untuk melaksanakan penelitian ini, adapun penelitian ini bertujuan 
untuk mengetahui pengaruh minat dan metode pembelajaran LKS model Word Square terhadap hasil belajar IPA Biologi siswa kelas VII SMP Negeri 2 Jayapura

\section{METODE PENELITIAN}

Penelitian ini merupakan penelitian kuantitatif dengan menggunakan rancangan eksperimen semu, dimana sampel dalam populasi diberi perlakuan tanpa adanya kelas kontrol. Penelitian ini dilaksanakan pada bulan Februari sampai bulan Mei Tahun 2017 di SMP Negeri 2 Jayapura. Populasi dalam penelitian ini adalah seluruh siswa kelas VII SMP Negeri 2 Jayapura yang tersebar dalam 13 kelas. Sampel dalam penelitian ini adalah seluruh siswa kelas VII J, VII K, dan VII L dengan jumlah siswa sebanyak 116 orang yang dibagi menjadi 4 kelas. Pembagian 4 kelas ini berdasarkan desain penelitian yang digunakan yaitu anava dua jalan. Variabel dalam penelitian ini adalah model pembelajaran Lembar Kerja Siswa (LKS) Model Word Square, metode pembelajaran, minat tinggi, minat rendah, sebagai variabel bebas dan hasil belajar IPA Biologi sebagai variabel terikat. Desain penelitian ini menggunakan desain Anava dua Jalan untuk pengujian hipotesis yang terdiri dari dua sampel.

Tabel 1. Desain penelitian

\begin{tabular}{ccc}
\hline \multirow{2}{*}{$(\mathrm{B})$} & & $(\mathrm{A})$ \\
\cline { 2 - 3 } & $(\mathrm{A} 1)$ & $(\mathrm{A} 2)$ \\
\hline (B1) & $\mathrm{A} 1, \mathrm{~B} 1$ & $\mathrm{~A} 2, \mathrm{~B} 1$ \\
\hline (B2) & $\mathrm{A} 1, \mathrm{~B} 2$ & $\mathrm{~A} 2, \mathrm{~B} 2$ \\
\hline
\end{tabular}

Keterangan :

A : Metode Pembelajaran

A1 : Model Pembelajaran Lembar Kerja Siswa Model word Square

A2 : Metode Ceramah

B : Minat

B1 : Minat Tinggi

B2 : Minat Rendah

Pengujian validitas angket minat dalam penelitian ini menggunakan Rumus Pearson Produk Momen sebagai berikut :

$$
\mathrm{r}_{\mathrm{xy}}=\frac{\mathrm{N} \sum \mathrm{XY}-\left(\sum \mathrm{X}\right)\left(\sum \mathrm{Y}\right)}{\sqrt{\mathrm{n} \sum \mathrm{x}^{2}-\left(\sum \mathrm{x}\right)^{2} \sqrt{\mathrm{n} \sum \mathrm{Y}^{2}-\left(\sum \mathrm{Y}\right)^{2}}}}
$$


Keterangan :

r $\quad$ : koefisian korelasi

$\sum X \quad$ : jumlah skor item

$\sum Y \quad$ : jumlah skor total

$N \quad$ : jumlah responden

(Kasmadi dkk, 2014)

Perhitungan reliabilitas angket minat dalam penelitian ini menggunakan Rumus Alpha Cronbach sebagai berikut:

$$
r=\left[\frac{k}{(k-1)}\right]\left[1-\frac{\sum \sigma_{b}^{2}}{\sigma_{b}^{2}}\right]
$$

Keterangan :

r $\quad$ : koefisien reliabilitas alpha cronbach

$\mathrm{k} \quad$ : banyak butir pertanyaan

$\sum \sigma_{b}^{2} \quad$ : total varians butir

$\sigma_{b}^{2} \quad$ : total varians

(Kasmadi dkk, 2014)

Pengujian validitas tes hasil belajar dalam penelitian ini menggunakan Rumus Point Biserial sebagai berikut :

Keterangan :

$$
P_{p b i s}=\frac{\left(\mu_{+}-\mu_{x}\right)}{\sigma_{x}} \frac{\sqrt{p}}{q}
$$

$P_{\text {pbis }}:$ koefisien korelasi point biserial

$\mu_{+} \quad$ : rata-rata skor untuk yang menjawab benar

$\mu_{x} \quad$ : rata-rata skor untuk seluruhnya

$\sigma_{x} \quad$ : simpangan baku

$p \quad$ : proporsi untuk yang menjawab yang benar

q : sama dengan 1-p

(Kasmadi dkk, 2014)

Perhitungan reliabilitas tes hasil belajar dalam penelitian ini menggunakan Rumus KR-20 (Kuder Richardson) sebagai berikut :

$$
r_{11}=\left(\frac{n}{n-1}\right) \frac{S D_{t}^{2} \sum(p q)}{S D_{t}^{2}}
$$

Keterangan:

$$
\begin{array}{ll}
r_{11} & \text { : reliabilitas tes sacara keseluruhan } \\
n & : \text { jumlah responden } \\
\mathrm{S} & \text { : standar deviasi } \\
p & \text { : proporsi jumlah peserta yang menjawab benar butir ke-1 } \\
q \quad \text { : proporsi subjek yang mendapat skor } 0 \\
\sum(p q): \text { jumlah perkalian p dan } \mathrm{q} \\
\text { (Kasmadi dkk, 2014) }
\end{array}
$$


Uji prasyarat dilakukan melalui uji normalitas dan homogenitas dilakukan untuk mengetahui apakah data berdistribusi secara normal dan varians data yang bersifat homogen atau tidak. Langkah-langkah uji normalitas sebagai berikut: Pengujian normalitas data penelitian melalui jalur analisis yang bersifat parametrik dengan menggunakan uji Kolmogorov-Smirnov (Djoyosentoso, 2014). Langkah-langkah yang harus ditempuh dalam pengujian adalah:

1. Merumuskan hipotesis:

$\mathrm{H}_{0}$ : Sampel berasal dari populasi berditribusi normal

$\mathrm{H}_{1}$ : Sampel berasal dari populasi berdistribusi tidak normal

2. Menghitung komulatif proporsi $(\mathrm{kp})$

3. Data ditransformasi ke skor baku $\mathrm{Z}_{\mathrm{i}}=\frac{x_{i-\bar{x}}}{S D}$

4. Menentukan luas kurva $\mathrm{Z}_{\mathrm{i}}\left(\mathrm{Z}_{\text {tabel }}\right)$

5. Menentukan $\mathrm{a}_{1}$ dan $\mathrm{a}_{2}$

$\mathrm{a}_{1}=$ selisih $\mathrm{Z}_{\text {tabel }}$ dan kp pada batas bawah

$\mathrm{a}_{2}=$ selisih $\mathrm{Z}_{\text {tabel }}$ da $\mathrm{kp}$ batas atas

6. Menentukan harga $T_{\text {tabel }}$

Untuk $\mathrm{n}=30$ dari $\alpha=0.05$, diperoleh $\mathrm{T}_{\text {tabel }}=242$

Untuk $\mathrm{n}=60$ dari $\alpha=0.05$, diperoleh $\mathrm{T}_{\text {tabel }}=\frac{1.6}{\sqrt{n}}=0.17557$

7. Kriteria pengujian adalah jika $\mathrm{T}_{\text {hitung }} \leq \mathrm{T}_{\text {tabel }}$ maka $H_{0}$ diterima

8. Kesimpulan: $\mathrm{T}_{\text {hitung }} \leq \mathrm{T}_{\text {tabel }}$ maka sampel berasal dari populasi berdistribusi normal.

Uji homogenitas merupakan pengujian asumsi dengan tujuan untuk membuktikan data yang dianalisis berasal dari sampel dalam populasi yang homogen atau tidak. Uji homogenitas perlu dilakukan untuk memberi keyakinan apakah varians variabel bebas $\left(\mathrm{X}_{1}\right)$ dan $\left(\mathrm{X}_{2}\right)$ dapat mempengaruhi skor pada variabel terikat (Y) bersifat homogen atau tidak (Kasmadi dkk, 2014). Setelah uji prasyarat dilanjutkan dengan uji hipotesis menggunakan Anava dua jalan menurut (Djoyosentoso, 2014), langkah-langkah sebagai berikut:

1. Menghitung jumlah kaudrat (JK) untuk beberapa sumber variansi, yaitu Total (T), Antar (A), Antar (B), interaksi (AB), dan dalam (D).

2. Menentukan derajat frekuensi (df) masing-masing sumber varians.

3. Menentukan rata-rata jumlah kuadrat (RJK).

4. Menentukan $F_{\text {hitung. }}$

5. Menyusun tabel ANAVA.

6. Kriteria pengujian

Jika $F_{\text {hitung }}>F_{\text {tabel }}$ pada taraf signifikan yang dipilih dengan df pembilang adalah df yang sesuai, maka $\mathrm{H}_{1}$ diterima dan sebaliknya. Hipotesis statistik dalam penelitian ini sebagai berikut.

$$
\begin{aligned}
\text { 1. } H_{1}: \mu_{1} & \geq \mu_{2} \\
H_{0}: \mu_{1} & <\mu_{2}
\end{aligned}
$$


2. $H_{1}: \mu_{1} \geq \mu_{2}$

$H_{0}: \mu_{1}<\mu_{2}$

3. $H_{1}: \mu_{1}=\mu_{2}$

$H_{0}: \mu_{1} \neq \mu_{2}$

\section{HASIL PENELITIAN}

Berdasarkan tabel 2 hasil data statistik deskriptif memperlihatkan keadaan pada variabel A1B1 dengan skor range 30, minimum 65, maksimum 95, jumlah skor (sum) 4825, rata-rata (mean) 80.42, simpangan baku (std.deviation) 6.397, dan varians 40.925. Variabel A1B2 dengan skor range 30, minimun 40, maksimum 70, jumlah skor (sum) 3355, rata-rata (mean) 59.91, simpangan baku (std.devation) 8.969, dan varians 80.446. Variabel A2B1 dengan skor range 30, minimum 50, maksimum 80, jumlah skor (sum) 4115, rata-rata (mean) 68.58, simpangan baku (std.deviation) 7.816, dan varians 61.095. Variabel A2B2 dengan skor range 35, minimum 30, maksimum 60, jumlah skor (sum) 2400, rata-rata (mean) 42.86, simpangan baku (std.devation) 9.138, dan varians 83.506.

Tabel 2. Hasil Analisis Statistik Deskriptif

\begin{tabular}{lcccccccc}
\hline \multicolumn{10}{c}{ Descriptive Statistics } \\
\cline { 1 - 7 } Variabel & N & Range & Minimum & Maximum & Sum & Mean & Std. Deviation & Variance \\
\hline A1B1 & 60 & 30 & 65 & 95 & 4825 & 80.42 & 6.397 & 40.925 \\
\hline A1B2 & 56 & 30 & 40 & 70 & 3355 & 59.91 & 8.969 & 80.446 \\
\hline A2B1 & 60 & 30 & 50 & 80 & 4115 & 68.58 & 7.816 & 61.095 \\
\hline A2B2 & 56 & 35 & 30 & 60 & 2400 & 42.86 & 9.138 & 83.506 \\
\hline
\end{tabular}

Pengujian normalitas data hasil penelitian dengan menggunakan uji Kolmogorov-Smirnov. Tujuan pengujian ini digunakan untuk mengetahui apakah data tersebut berasal dari populasi yang berdistribusi normal atau tidak.

Tabel 3. Hasil Deskripsi Uji Normalitas Data

\begin{tabular}{cccccc}
\hline \multicolumn{5}{c}{ Kolmogorov-Smirnov } \\
\hline NO & Variabel & $\mathrm{T}_{\text {hitung }}(\mathrm{sig})$. & $\mathrm{T}_{\text {tabel }}(\mathrm{sig})$. & Keputusan & Kesimpulan \\
\hline 1 & A1B1 & 0.005 & 0.05 & $H_{0}$ diterima & Normal \\
\hline 2 & A1B2 & 0.000 & 0.05 & $H_{0}$ diterima & Normal \\
\hline 3 & A2B1 & 0.001 & 0.05 & $H_{0}$ diterima & Normal \\
\hline 4 & A2B2 & 0.000 & 0.05 & $H_{0}$ diterima & Normal \\
\hline
\end{tabular}


1. Pengujian Normalitas Data Untuk Kelompok Lembar Kerja Siswa (LKS) Model Word Square Terhadap Kelompok Siswa Minat Tinggi (A1B1).

Berdasarkan hasil perhitungan, diperoleh nilai $\mathrm{T}_{\text {hitung }}$ taraf sig. 0.005 dan $\mathrm{T}_{\text {tabel }}$ taraf sig. 0.05. Kerena $\mathrm{T}_{\text {hitung }}<\mathrm{T}_{\text {Tabel }}$ maka $H_{0}$ diterima, sehingga dapat disimpulkan bahwa data berasal dari populasi yang berdistribusi normal.

2. Pengujian Normalitas Data Untuk Kelompok Lembar Kerja Siswa Model Word Square Terhadap Kelompok Siswa Minat Rendah (A1B2).

Berdasarkan hasil perhitungan, diperoleh nilai $\mathrm{T}_{\text {hitung }}$ taraf sig. 0.000 dan $\mathrm{T}_{\text {Tabel }}$ taraf sig. 0.05. Karena $\mathrm{T}_{\text {hitung }}<\mathrm{T}_{\text {Tabel }}$ maka $H_{0}$ diterima, sehingga dapat disimpulkan bahwa data berasal dari populasi yang berdistribusi normal.

3. Pengujian Normalitas Data Untuk Kelompok Ceramah Terhadap Kelompok Siswa Minat Tinggi (A2B1).

Berdasarkan hasil perhitungan, diperoleh nilai $\mathrm{T}_{\text {hitung }}$ taraf sig. 0.001 dan $\mathrm{T}_{\text {Tabel }}$ taraf sig. 0.05. Karena $\mathrm{T}_{\text {tabel }}<\mathrm{T}_{\text {Tabel }}$ maka $H_{0}$ diterima, sehingga dapat disimpulkan bahwa data berasal dari populasi yang berdistribusi normal.

4. Pengujian Normalitas Data Untuk Kelompok Ceramah Terhadap Kelompok Siswa Minat Rendah (A2B2).

Berdasarkan hasil perhitungan, diperoleh nilai $\mathrm{T}_{\text {tabel }}$ taraf sig. 0.000 dan $\mathrm{T}_{\text {Tabel }}$ taraf sig. 0.05. Karena $\mathrm{T}_{\text {hitung }}<\mathrm{T}_{\text {Tabel }}$ maka $H_{0}$ diterima, sehingga dapat disimpulkan bahwa data berasal dari populasi yang berdistribusi normal

Uji homogenitas merupakan pengujian asumsi dengan tujuan untuk membuktikan data yang dianalisis berasal dari populasi yang berdistribusi homogen atau tidak. Hal tersebut dimaksudkan untuk memberi keyakinan apakah varians pada variabel bebas $\left(\mathrm{X}_{1}\right)$ dan $\left(\mathrm{X}_{2}\right)$ mempengaruhi varians skor pada variabel terikat (Y).

Tebel 4. Pengujian Homogenitas Data

\begin{tabular}{ccccc}
\hline \multicolumn{5}{c}{ Kolmogorov-Smirnov } \\
\\
\hline Variabel & $\mathrm{F}$ & df 1 & df 2 & Sig. \\
\hline $\begin{array}{c}\text { Hasil LKS Model Word } \\
\text { square }\end{array}$ & 3.943 & 1 & 114 & 0.059 \\
\hline Metode ceramah & 3.939 & 1 & 114 & 0.056 \\
\hline
\end{tabular}

Berdasarkan hasil perhitungan pengujian homogenitas data, diperoleh hasil varians pada variabel LKS model Word Square dengan nilai $\mathrm{T}_{\text {Hitung }}$ taraf sig. 0.059 lebih besar dari $\mathrm{T}_{\text {Tabel }}$ taraf sig. 0.05. Karena $\mathrm{T}_{\text {Hitung }}>\mathrm{T}_{\text {Tabel }}$ maka $H_{1}$ diterima, dan hasil varians pada perhitungan variabel metode ceramah dengan nilai $\mathrm{T}_{\text {hitung }}$ taraf sig. 0.056 lebih besar dari $\mathrm{T}_{\text {tabel }}$ taraf sig. 0.05 . Karena $\mathrm{T}_{\text {hitung }}>$ $\mathrm{T}_{\text {tabel }}$ maka $H_{1}$ diterima. Hal ini menunjukkan penerimaan $H_{1}$ sehingga dapat disimpulkan bahwa varians seluruh variabel bersifat homogen. Pengujian prasyaratan normalitas dan homogenitas telah terpenuhi sebagai syarat dilakukan 
pengujian hipotesis, maka dilanjutkan ke pengujian prasyaratan yang terakhir yaitu pengujian hipotesis.

Berdasarkan hasil deskripsi yang ditunjukkan pada tabel 4 untuk variabel minat tinggi diketahui nilai rata-rata (Mean) 74.87, simpangan baku (Std. Deviation) sebesar 7.780, nilai minimum sebesar 61, nilai maksimum 91, nilai varians sebesar 60.524 sedangkan veriabel minat rendah di ketahui nilai rata-rata (Mean) 56.04, simpangan baku (Std. Deviation) sebesar 3.785 nilai minimum sebesar 50, nilai maksimum 60, nilai varians sebesar 14.326 .

Tabel 5. Deskripsi Data Minat Belajar

\begin{tabular}{cccccccc}
\hline Variabel & $\mathbf{N}$ & Mean & Minimum & Maksimum & $\begin{array}{c}\text { Std. } \\
\text { Devation }\end{array}$ & Varians & $\begin{array}{c}\text { Total } \\
\text { Sum (\%) }\end{array}$ \\
\hline $\begin{array}{c}\text { Minat } \\
\text { Tinggi }\end{array}$ & 60 & 74.87 & 61 & 91 & 7.780 & 60.524 & $58.9 \%$ \\
\hline $\begin{array}{c}\text { Minat } \\
\text { Rendah }\end{array}$ & 56 & 65.04 & 50 & 60 & 3.785 & 14.326 & $41.1 \%$ \\
\hline Total & 116 & 65.78 & 50 & 91 & 11.279 & 127.219 & $100 \%$ \\
\hline
\end{tabular}

Berdasarkan tahap pengujian normalitas dan homogenitas data dikatakan normal dan homogen maka dilakukan pengujian hipotesis menggunakan analisis varians (anava) dua jalan. Ringkasan hasil pengujian anava dari data yang diperoleh adalah sebagai berikut :

Tabel 6. Ringkasan Hasil Pengujian Hipotesis

\begin{tabular}{|c|c|c|c|c|c|c|}
\hline \multirow[t]{2}{*}{ No } & \multirow[t]{2}{*}{ Variabel } & \multirow{2}{*}{$\begin{array}{c}\text { Pengaruh } \\
\text { Utama }\end{array}$} & \multirow{2}{*}{$\begin{array}{l}\text { Pengaruh } \\
\text { Interaksi }\end{array}$} & \multicolumn{2}{|c|}{ F tabel } & \multirow[t]{2}{*}{ Keputusan } \\
\hline & & & & $\alpha 5 \%$ & $\alpha 1 \%$ & \\
\hline 1 & $\begin{array}{l}\text { A1B1, } \\
\text { A2B1 }\end{array}$ & 2.967 & - & 2.46 & 3.51 & $H_{l}$ diterima \\
\hline 2 & $\begin{array}{l}\text { A1B2, } \\
\text { A2B2 }\end{array}$ & 2.952 & - & 2.46 & 3.51 & $H_{l}$ diterima \\
\hline 3 & $A * B$ & - & 3.776 & 2.46 & 3.51 & $H_{l}$ diterima \\
\hline
\end{tabular}

\section{PEMBAHASAN}

Berdasarkan tabel 6 di atas data variabel minat belajar diperoleh nilai ratarata minat tinggi 74.87 sedangkan variabel minat rendah diperoleh nilai rata-rata 65.04. Dengan demikian dapat dideskripsikan bahwa, salah satu faktor internal (faktor dari dalam diri siswa) yang turut nenentukan keberhasilan siswa/i di SMP Negeri 2 Jayapura khususnya kelas VIIJ, VIIK dan VIIL adalah minat belajar. Menurut Sudjana (1989) mengemukakan bahwa "hasil belajar yang dicapai siswa dipengaruhi oleh dua faktor yaitu faktor dari dalam diri siswa itu dan faktor yang 
datang dari luar diri siswa atau faktor lingkungan. Minat yang timbul dari dalam diri siswa akan berpengaruh terhadap hasil belajar yang dicapai oleh siswa tersebut, dimana minat menjadi sumber motivasi yang kuat dalam partisipasi dan keaktifan siswa dalam proses pembelajaran. Untuk membangkitkan minat belajar siswa, guru memiliki peran penting dalam proses belajar mengajar.

Guru harus menerapkan metode pembelajaran yang efektif sehingga dapat mempengaruhi hasil belajar yang dicapai oleh siswa dan di dukung oleh faktor internal yaitu minat belajar yang timbul dari dalam diri siswa. Pengaruh rata-rata hasil belajar kelompok siswa yang diajarkan menggunakan Lembar Kerja Siswa (LKS) Model Word Square dan kelompok siswa yang diajar menggunakan metode ceramah pada kelompok siswa yang memiliki minat tinggi. Karena $F_{\text {hitung }}$ $2.967>\mathrm{F}_{\text {tabel }} 2.46$ maka $\mathrm{H}_{1}$ diterima. Dengan demikian dideskripsikan bahwa hasil belajar IPA Biologi kelompok siswa yang diajarkan menggunakan Lembar Kerja Siswa (LKS) Model Word Square lebih tinggi dari pada metode ceramah. Perolehan nilai rata-rata tes hasil belajar menggunakan Lembar Kerja Siswa (LKS) Model Word Square pada siswa yang memiliki minat tinggi dengan perolehan nilai rata-rata 80.42 dan perolehan nilai rata-rata tes hasil belajar IPA Biologi menggunakan metode ceramah pada siswa yang memiliki minat tinggi dengan nilai rata-rata 68.58. Maka perolehan nilai rata-rata pembelajaran menggunakan Lembar Kerja Siswa (LKS) Model Word Square berpengaruh terhadap pembelajaran menggunakan metode ceramah pada siswa yang memiliki minat tinggi.

Berdasarkan hasil pengujian hipotesis dapat dideskripsikan bahwa penggunaan Lembar Kerja Siswa (LKS) Model Word Square berpengaruh terhadap siswa yang memiliki minat tinggi. Pengaruh pembelajaran dengan Lembar Kerja Siswa (LKS) Model Word Square dapat meningkatkan keaktifan dan keterlibatan siswa dalam kegiatan belajar dan mengajar. Dilihat dari kelebihan penggunaan Lembar Kerja Siswa (LKS) Model Word Square membantu siswa untuk melatih ketelitian, ketepatan dalam menjawab dan mencari jawaban pada lembar kerja Word Square, sehingga membuat siswa lebih fokus dan berkonsentrasi dalam mengikuti proses pembelajaran dari awal sampai akhir pembelajaran. Peningkatan keaktifan siswa akan sangat berpengaruh terhadap pengetahuan dan pemahaman akan materi yang dipelajari oleh siswa setelah mengalami proses belajar dan mengajar, sehingga hasil belajar yang diperoleh siswa akan meningkat.

Meningkatnya hasil belajar siswa dapat dilihat dengan adanya minat yang timbul dari dalam diri siswa tersebut, karena minat merupakan suatu rasa kesukaan atau ketertarikan terhadap suatu objek yang disukai tanpa adanya menyuruh, menurut Slemeto (2010). Keaktifan dan keterlibatan siswa terlihat ketika pembelajaran dengan lembar Word Square siswa dapat berinteraksi dengan teman sebaya untuk mencari jawaban dalam lembar Word Square dan 
mencocokkan dengan butir pertanyaan yang tersedia dalam lembar Word Square, sehingga pusat perhatian siswa tertuju pada proses belajar dan mengajar.

Pada lembar Word Square terdapat kumpulan huruf pada kotak-kotak kata yang berisikan konsep yang harus ditemukan oleh siswa sesuai dengan butir pertanyaan. Interaksi yang terlihat antara siswa dengan teman sebaya terjadi ketika proses saling bertukar pikiran untuk mencari dan menemukan konsep yang terdapat pada kotak-kotak huruf yang berisikan jawaban dari butir pertanyaan pada lembar Word Square. Dengan membagikan lembar Word Square sebagai alat untuk mengukur tingkat pemahaman akan materi yang telah diajarkan. Keaktifan dan keterlibatan siswa dalam pembelajaran menggunakan Lembar Kerja Siswa (LKS) Model Word Square dapat menciptakan suasana belajar yang menyenangkan karena adanya interaksi antara siswa dengan teman sebaya yang tidak membuat siswa merasa bosan akan materi yang dipelajari sebab siswa terlibat langsung dalam proses belajar.

Model pembelajaran lembar Word Square merupakan salah satu model pembelajaran yang menekankan pada peningkatan partisipasi aktif belajar siswa untuk belajar mandiri. Proses pembelajaran menggunakan Lembar Kerja (LKS) Model Word Square dapat melatih tingkat pemahaman, konsentrasi, ketelitian dan ketepatan dalam meningkatkan hasil belajar siswa terhadap pelajaran yang diajarkan.Pembelajaran pada kelompok siswa yang menggunakan metode ceramah tidak berpengaruh terhadap hasil belajar siswa yang memiliki minat tinggi dengan perolehan nilai rata-rata lebih rendah dibandingkan pembelajaran menggunakan Lembar Kerja (LKS) Model Word Square dengan perolehan nilai lebih tinggi.

Pembelajaran menggunakan metode ceramah tidak berpengaruh terhadap siswa yang memiliki minat tinggi, karena pembelajaran metode ceramah hanya fokus pada penjelasan guru yang lebih aktif dalam proses belajar dan mengajar dan siswa sebagai pendengar yang pasif. Meskipun metode ceramah lebih menekankan keaktifan guru dari pada siswa, tetapi keberhasilan akan penggunaan metode ceramah terhadap penjelasan guru dalam kata-kata dan kalimat akan mudah dipahami oleh siswa hanya saja peranan siswa dalam metode ceramah kurang aktif dan mudah bosan.

Timbulnya rasa bosan dalam diri siswa akan berpengaruh terhadap hasil belajar yang diperoleh, sebab pengetahuan dan pemahaman akan materi yang dipalajari oleh siswa terbatas dan mudah terlupakan meskipun siswa memiliki minat yang tinggi. Siswa yang memiliki minat tinggi bila dalam proses belajar dan mengajar lebih aktif akan berpengaruh terhadap perolehan hasil balajar yang memuaskan. Jadi dalam penelitian ini menunjukkan bahwa pembelajaran menggunakan Lembar Kerja Siswa (LKS) Model Word Square lebih efektif dari pada pembelajaran menggunakan metode ceramah pada siswa yang memiliki minat tinggi. 
Penelitian ini sejalan dengan penelitian Agus (2015) di MI Mraggen Demak yang mengemukakan bahwa penggunaan model pembelajaran Word Square lebih baik dari pada model pembelajaran konvensional. Pengaruh rata-rata hasil belajar kelompok siswa yang diajarkan menggunakan Lembar Kerja Siswa (LKS) Model Word Square dan kelompok siswa yang diajar menggunakan metode ceramah pada kelompok siswa yang memilki minat rendah. Karena $F_{\text {hitung }}$ $2.952>\mathrm{F}_{\text {tabel }} 2.46$ maka $H_{l}$ diterima. Dengan demikian dideskripsikan bahwa hasil belajar IPA Biologi kelompok siswa yang diajarkan menggunakan Lembar Kerja Siswa (LKS) Model Word Square lebih tinggi dari pada metode ceramah pada siswa yang memiliki minat rendah. Perolehan nilai rata-rata tes hasil belajar menggunakan Lembar Kerja Siswa (LKS) Model Word Square pada siswa yang memiliki minat rendah dengan perolehan nilai rata-rata 59.91 dan perolehan nilai rata-rata tes hasil belajar IPA Biologi menggunakan metode ceramah pada siswa yang memiliki minat rendah dengan nilai rata-rata 42.84. Maka perolehan nilai rata-rata pembelajaran menggunakan Lembar Kerja Siswa (LKS) Model Word Square berpengaruh terhadap pembelajaran menggunakan metode ceramah pada siswa yang memiliki minat rendah.

Berdasarkan pengujian hasil hipotesis dapat dideskripsikan bahwa hasil belajar IPA Biologi kelompok siswa yang diajarkan menggunakan Lembar Kerja Siswa (LKS) Model Word Square berpengaruh terhadap siswa yang memiliki minat rendah. Pengaruh pembelajaran dengan Lembar Kerja Siswa (LKS) Model Word Square dapat meningkatkan keaktifan dan keterlibatan siswa dalam kegiatan belajar dan mengajar meskipun minat siswa rendah. Dapat dijelaskan bahwa kelebihan penggunaan Lembar Kerja Siswa (LKS) Model Word Square lebih menekankan adanya keaktifan siswa untuk melatih ketelitian dan ketepatan dalam menyari dan menjawab dalam lembar kerja Word Square. Keaktifan dan keterlibatan siswa dalam proses belajar terlihat ketika siswa berinteraksi dengan teman sebaya dalam bertukar pikiran untuk mencari jawaban pada lembar kerja Word Squar.

Pada lembar kerja Word Square terdapat kotak-kotak kata yang berisikan kumpulan huruf dan terkandung konsep yang harus dicari dan ditemukan oleh siswa sesuai dengan butir pertanyaan yang telah tersedia. Meskipun siswa memiliki minat rendah terhadap materi pembelajaran, namun adanya pembelajaran menggunakan Lembar Kerja Siswa (LKS) Model Word Square terlihat siswa turut aktif dalam berinteraksi dengan teman sebaya untuk menyari jawaban pada lembar kerja Word Square. Sehingga timbulnya kebosanan dari dalam diri siswa tidak terlihat karena adanya peranan aktif untuk belajar mandiri dan memberikan perhatiannya terhadap pembelajaran yang sedang berlangsung. Peranan aktif yang ditimbulkan oleh siswa yang memiliki minat rendah sangat membantu peningkatan pengetahuan dan mempermudah mengingat materi yang dipelajari serta dapat meningkatkan hasil belajar siswa. 
Model pembelajaran lembar Word Square merupakan salah satu model pembelajaran yang menekankan pada peningkatan partisipasi aktif belajar siswa untuk belajar mandiri. Proses pembelajaran menggunakan Lembar Kerja (LKS) Model Word Square dapat melatih tingkat pemahaman, konsentrasi, ketelitian dan ketepatan dalam meningkatkan hasil belajar siswa terhadap materi yang diajarkan. Pembelajaran pada kelompok siswa yang menggunakan metode ceramah tidak berpengaruh terhadap hasil belajar siswa yang memiliki minat rendah dengan perolehan nilai rata-rata lebih rendah dibandingkan dengan pembelajaran Lembar Kerja Siswa (LKS) Model Word Square yang memperoleh nilai rata-rata lebih tinggi. Pembelajaran menggunakan metode ceramah tidak berpengaruh terhadap siswa yang memiliki minat rendah, karena dalam pembelajaran metode ceramah guru lebih aktif dalam menjelaskan materi dan siswa hanya sebagai pendengar pasif.

Penggunaan metode ceramah yang lebih menekankan pada keaktifan guru ketika menjelaskan materi dengan kata-kata dan kalimat dalam proses belajar dan mengajar, sehingga pasifnya siswa akan menimbulkan rasa bosan dari dalam diri siswa kepada penjelasan guru dalam menyampaikan materi. Kepasifan siswa akan berdampak pada menurunnya minat siswa terhadap materi pelajaran dan siswa tidak mempunyai keinginan untuk mengikuti pelajaran dan kurangnya perhatian siswa terhadap penjelasan guru ketika pembelajaran berlangsung. Terkadang kurangnya minat terhadap pelajaran siswa tidak mengikuti proses pembelajaran namun siswa terlihat aktif bermain pada saat proses pembelajaran berlangsung. Hal ini akan berdampak pada pemahaman dan pengetahuan terhadap materi yang dipelajari sehingga mudah terlupakan dan akan mempengaruhi hasil belajar siswa. Jadi dalam penelitian ini dapat disimpulkan bahwa pembelajaran menggunakan Lembar Kerja Siswa (LKS) Model Word Square hasil belajar lebih baik dari pada pembelajaran menggunakan metode ceramah pada siswa yang memiliki minat rendah.

Penelitian ini sejalan dengan penelitian Gusmitawati (2012) yang menunjukkan bahwa nilai rata-rata hasil belajar pada siklus pertama memperoleh nilai 60 dengan presentasi 45,71\% sedangkan siklus kedua memperoleh nilai 74,26 dengan presentasi $85,71 \%$ sehingga disimpulkan bahwa penerapan model pembelajaran Word Square dapat meningkatkan hasil belajar siswa mata pelajaran IPS siswa kelas IV B di SD Negeri Cibalagung 5 Bogor. Selain itu, penerapan model pembelajaran ini dapat meningkatkan keaktifan, kerjasama dalam proses pembelajaran. Pengaruh Interaksi Antara Metode Pembelajaran Dengan Minat dimana Karena $\mathrm{F}_{\text {hitung }} 3.776>\mathrm{F}_{\text {tabel }} 2.46$ maka $H_{l}$ diterima. Dengan demikian dapat dideskripsikan bahwa terdapat pengaruh interaksi yang sangat signifikan antar metode pembelajaran dan minat siswa terhadap hasil belajar IPA Biologi.

Berdasarkan hasil pengujian hipotesis dapat dideskripsikan bahwa terdapat pengaruh interaksi antara metode pembelajaran dan minat siswa. Hasil belajar yang akan dicapai oleh siswa akan berpengaruh jika digunakan suatu metode 
pembelajaran yang dapat meningkatkan minat siswa terhadap pelajaran. Metode pembelajaran merupakan suatu upaya yang dapat diterapkan oleh para pendidik guna dalam proses belajar dan mengajar dapat menyenangkan sehingga dapat menciptakan suatu bentuk interaksi antara pendidik dengan siswa agar tercapai sesuai dengan tujuan. Pemilihan dan penerapan suatu metode pembelajaran sangat penting dalam proses belajar dan mengajar, sehingga keinginan dan kesukaan siswa terhadap suatu pelajaran nampak menyenangkan serta membuat siswa terlihat lebih aktif dalam belajar. Selain penerapan metode pembelajaran, minat merupakan faktor pendukung karena minat adalah rasa kesukaan atau rasa ketertarikan pada suatu hal yang diinginkan, tanpa adanya keterpaksaan. Minat yang ditimbulkan oleh siswa akan sangat berpengaruh terhadap tujuan pencapaian hasil belajar yang efektif.

Penelitian ini sejalan dengan penelitian Muldayanti (2013), tujuan penelitian ini adalah untuk mengetahui pengaruh penggunaan metode pembelajaran dengan TGT (Team Games Tournament) dan STAD (Student Team Achievement Division) terhadap prestasi belajar biologi ditinjau dari keingintahuan dan minat belajar siswa. Hasil analisis diperoleh bahwa 1), ada pengaruh minat belajar tinggi dan rendah terhadap prestasi belajar biologi, 2) terdapat interaksi antara motode pembelajaran, keingintahuan tinggi dan rendah, minat belajar tinggi dan rendah terhadap prestasi belajar biologi.

\section{SIMPULAN}

Simpulan hasil penelitian ini sebagai berikut:

1. Deskripsi data minat belajar diperoleh variabel minat tinggi nilai rata-rata 74,87 dan variabel minat rendah diperoleh nilai rata-rata 65.04. Minat yang timbul dari dalam diri siswa sangat berpengaruh terhadap hasil belajar yang dicapai dalam proses pembelajaran.

2. Pembelajaran menggunakan Lembar Kerja Siswa (LKS) Model Word Square sangat berpengaruh terhadap hasil belajar dengan nilai rata-rata 80.42 dari pembelajaran menggunakan metode ceramah dengan nilai rata-rata 68.58 pada siswa yang memiliki minat tinggi.

3. Pembelajaran menggunakan Lembar Kerja Siswa (LKS) Model Word Square sangat berpengaruh terhadap hasil belajar dengan nilai rata-rata 59.91 dari pembelajaran menggunakan metode ceramah dengan nilai rata-rata 42.86 pada siswa yang memiliki minat rendah.

4. Terdapat pengaruh interaksi yang sangat signifikan antara metode pembelajaran dengan minat atau pengaruh metode terhadap hasil belajar IPA Biologi bergantung pada minat siswa dengan hasil perhitungan $\mathrm{F}_{\text {hitung }} 3.776>$ $\mathrm{F}_{\text {tabel }} 2.46$. 


\section{DAFTAR PUSTAKA}

Agus A. (2015). Efektivitas Penggunaan Model Pembelajaran Word Square Terhadap Hasil Belajar Materi Pokok Mengenal Hijrah Nabi Muhammad SAW Ke Medinah Pada Siswa Kelas V MI Futuhiyyah Mranggen Demak Tahun Ajaran 2014/2015. (SKRIPSI). Universitas Islam Negeri Walisongo. Semarang.

Dewi, S \& Islamis. (2012). Jurnal: Penerapan Model Pembelajaran Kooperatif Lembar Kerja Siswa model word Square Untuk Meningkatkan Prestasi Belajar Siswa Pada Pembelajaran Kimia Pokok Bahasan Koloid Di Kelas XI Sman 4 Pekanbaru. Pendidikan UniversitasRiau.(http://repository.unri.ac.id/bitstream/123456789/1212/1/J URNAL\%20SRIYANA\%20DEWI.pdf, diakses tanggal 20 maret 2013) .

Djoyosentoso, T. (2014). Statistik Pendidikan (Teknik Analisis Data). Jayapura

Gusmitawati, Achmad \& Sumardi, (2012). Penerapan Model Pembelajaran Word Square Untuk Meningkatkan Hasil Belajar Pada Pelajaran Ilmu Pengetahuan Sosial. Bogor: Universitas Pakuan.

Kasmadi, Sunariah N. S. (2014). Panduan modern penelitian kuantitatif. Bandung: Alfabeta.

Muldayanti. (2013). Pembelajaran Biologi Model STAD Dan TGT Ditinjau Dari Keingintahuan Dan Minat Belajar Siswa. Universitas Muhammadyah Pontianak.

Slameto. (2003). Belajar dan Faktor-Faktor Yang Mempengaruhinya. Jakarta: PT.Rineka Cipta).

Slameto. (2010). Belajar Dan Faktor-Faktor Yang Mempengaruhi. Jakarta: PT Rineka Cipta

Sudaryono, M \& Rahayu. (2012). Pengembangan Instrumen Penilaian Pendidikan. Yogyakarta: Graha Ilmu.

Sudjana N. (1989). Dasar-Dasar Proses Belajar Mengajar. Bandung: Sinar Baru Algesindo. 